DOI: $10.2478 / v 10014-008-0002-9$

Agrovoc descriptors: aphidoidea, biological control, hymenoptera, natural enemies, beneficial organisms, parasitoids, biological control agents, aphidius matricariae, vegetables

Agris category codes: $\mathrm{H} 10$

University of Ljubljana

Biotechnical Faculty

Department of Agronomy

COBISS Code 1.01

\title{
Aphids (Aphididae) and their parasitoids in selected vegetable ecosystems in Slovenia
}

\author{
Katarina $\mathrm{KOS}^{1}$, Željko TOMANOVIĆ ${ }^{2}$, Olivera PETROVIĆ-OBRADOVIĆ ${ }^{3}$, Žiga \\ LAZNIK $^{4}$, Matej VIDRIH ${ }^{5}$, Stanislav TRDAN ${ }^{6}$
}

Received November 10, 2007, accepted April 28, 2007.

Delo je prispelo 10. novembra 2007; sprejeto 28. aprila 2007

\section{ABSTRACT}

Sucking insects, which representatives are also aphids, can cause important economic damage on cultivated and wild-growing plants in vegetable ecosystems. Our research was based on the aim of biological control, which is to limit or to control the pests with the use of their natural enemies. From April to November 2006 living aphids and their mummies were sampled together with their host plants in four locations in Slovenia. The samples have been taken from vegetables, weeds, within-crops plants and from the plants in the field borders. The occurrence of 18 aphid species was confirmed - 14 of them were parasitised. In our research 365 parasitoid specimens (17 species from 8 genera - Aphidius, Binodoxys, Diaeretiella, Ephedrus, Lipolexis, Lysiphlebus, Monoctonus, and Praon - of the family Aphidiidae) were recorded and identified. The most abundant parasitoid species were Aphidius matricariae (32.2\%) and Lysiphlebus fabarum (29.3\%). Parasitoid L. fabarum had the widest range of hosts; it parasitised aphids on the plants from 7 different botanical families. Sex ratio in our research confirmed the known fact, that in natural ecosystems female parasitoids are more numerous than the male parasitoids; this ratio in our research was $71 \%: 29 \%$.

Key words: aphids, Aphididae, biological control, Hymenoptera, natural enemies, parasitoids, Aphidius matricariae, Lysiphlebus fabarum

1 B. Sc., Jamnikarjeva 101, SI-1111 Ljubljana, e-mail: katarina.kos@bf.uni-lj.si

2 Assoc. Prof., Ph. D., University of Belgrade, Faculty of Biology, Studentski trg 16, SER-11000 Belgrade

3 Assoc. Prof., Ph. D., University of Belgrade, Faculty of Agriculture, Nemanjina 6, SER-11000 Belgrade

4 Teach. Assist., B. Sc., young researcher, Jamnikarjeva 101, SI-1111 Ljubljana

5 Teach. Assist., Ph. D., Jamnikarjeva 101, SI-1111 Ljubljana

6 Assist. Prof., Ph.D., Jamnikarjeva 101, SI-1111 Ljubljana 


\section{IZVLEČEK}

\section{PRAVE LISTNE UŠI (Aphididae) IN NJIHOVI PARAZITOIDI V IZBRANIH VRTNARSKIH} EKOSISTEMIH SLOVENIJE

Sesajoče žuželke, med katere spadajo tudi prave listne uši, lahko povzročajo pomembno gospodarsko škodo na gojenih in samoniklih rastlinah v vrtnarskih ekosistemih. V naši raziskavi smo se opirali na cilj biotičnega varstva rastlin, ki je z naravnimi sovražniki omejiti oziroma zatreti škodljivce. Od aprila do novembra 2006 smo na štirih lokacijah v Sloveniji vzorčili žive listne uši in ušje mumije na gostiteljskih rastlinah. Vzorce smo nabirali na vrtninah, plevelih, medsevkih in robnih posevkih. Ugotovili smo zastopanost 18 vrst pravih listnih uši, kar 14 vrst pa je bilo parazitiranih. $V$ nabranih vzorcev smo identificirali 365 osebkov parazitoidov listnih uši, ki so pripadali 17 različnim vrstam iz 8 rodov (Aphidius, Binodoxys, Diaeretiella, Ephedrus, Lipolexis, Lysiphlebus, Monoctonus in Praon) družine Aphidiidae. Najbolj množično sta se pojavljali vrsti Aphidius matricariae (32,2 \%) in Lysiphlebus fabarum (29,3 \%). Vrsta L. fabarum je imela tudi najširši spekter gostiteljev in je parazitirala uši na rastlinskih vrstah iz 7 različnih botaničnih družin. Če številčno primerjamo zastopanost spolov, lahko potrdimo znano dejstvo, da je število samic $v$ naravi večje od števila samcev; $v$ naši raziskavi je bilo omenjeno razmerje $71 \%: 29 \%$.

Ključne besede: prave listne uši (Aphididae), biotično varstvo rastlin, Hymenoptera, naravni sovražniki, parazitoidi, Aphidius matricariae, Lysiphlebus fabarum

\section{INTRODUCTION}

Aphids are an important group of plant insect pests. They have a high biological potential with some of aphids species (Aphididae) having more than ten generations in one year (Iversen and Harding, 2007). Because of their direct (sucking) and indirect (transmission of viruses and honeydew secretion) damage on cultivated and wild-growing plants, the producers of plant food, ornamental plants and feed for livestock control them in different ways. The most frequently mentioned control methods are spraying the plants with insecticides (Parker et al., 2006), the use of corresponding agrotechnical measures and in a lower extent the use of biological control agents (Du et al., 2004). In Slovenia, an exact number of aphid species is not known yet, but it is well known that producers most commonly control the aphids with the use of insecticides. This fact is influenced by relatively modest knowledge of producers about the biological control agents although this field of plant protection is systematicaly studied at the Biotechnical Faculty in Ljubljana from the beginning of the nineties of the past century (Milevoj, 1991, 1992, 1996, 1997; Trdan et al., 2006).

Among natural enemies of aphids, parasitoids have an important place (Tomanović and Brajković, 2001). Parasitoid is an insect, which larvae feed exclusively on or within the body of the host, which is always killed at the end. Only one host is needed for completion of the life cycle of a parasitoid, but usually more parasitoids are developed in one host. Parasitoids are specialized in selecting their host and are compared to the hosts - relatively big. Usually are parasitoids only in the stage of larva, meanwhile adult specimens are free-living and they feed with nectar of the plants and honeydew of the aphids (Minks in Harrewijn, 1988; Godfray, 1994). Parasitoids of aphids are mainly oligophagous or polyphagous. After the general classification less than one third from the total number of the species are monophagous (Starý, 1970). It is a known fact that adult parasitoids are frequently 
more sensitive on synthetic insecticides than their hosts (Hoffmann in Frodsham, 1993), what is worthy to consider when choosing the methods for controlling aphids.

The aim of our research was to identify and document parasitoid species of different noxious aphids in vegetable ecosystems and to find connections between species of aphids, their parasitoids and host plants. Prior to the beginning of present study it was known that parasitoids in Slovenia, in a contrast to some other groups of natural enemies, are poorly studied and that we need more information about them, specially in a relation to the future production of food. For latter it is foreseeing that it will supported more than till now with environmentally friendly systems of production.

The sampling took place from 20 April till 27 November 2006 in vegetable ecosystems on four different locations; namely at the Laboratory field of Biotechnical Faculty in Ljubljana, in Zalog, Velenje and Želimlje. Aphids, their parasitoids and host plants were collected on cultivated and wild-growing plants (Kos, 2007).

While sampling parasitoids, we modified the method according to the life cycle of parasitoids in their hosts (after Brajković in Tomanović, 2005). Parasitoids develop in yet living aphids, that is way we collected living aphids and their mummies in plactic posts, together with their host plants. The posts were covered with nylon patch, which enabled air flow and at the same time prevented the escape of aphids and later flown out parasitoids. The samples were marked with the successive number of sample, date of sampling and location (place of collecting) (Figure 1) Additionaly, we annotated also species of host plants, on which the samples were collected.

The samples of aphids for an identification were kept in an Eppendorf tube $(1.5 \mathrm{ml})$ together with $70 \%$ solution of ethanol. Each tube was marked with the number of sample according to the number on the pot. Because of the easier identification we gathered only bigger specimens of winged and non-winged aphids.

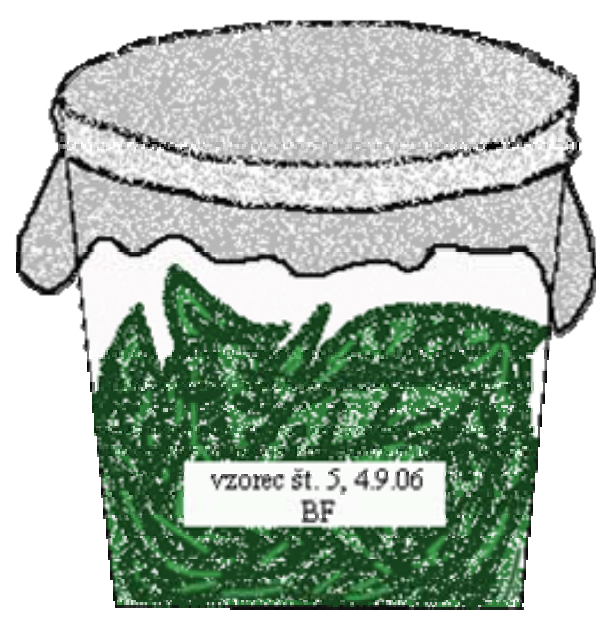

Figure 1: Schematic diagram of pot for collecting aphids, their mummies and host plants.

We left pots closed for 2 to 3 weeks, in some cases even longer, so that the wasps flew out from the mummies and died. Afterwards we put the content of the pot on the white surface and 
separated the parasitoids with the brush from the rest of the content. The parasitoids were kept in the vessels, which were marked with the corresponding number of the sample. Identification of aphids was performed on the Faculty of Agriculture in Zemun and identification of parasitoids was done on the Faculty of Biology in Belgrade.

\section{$3 \quad$ RESULTS AND DISCUSSION}

We sampled aphids on 36 different host plants from 13 botanical families. The very same or related species of host plants we treated in the experiment repeatedly in growing season. We found parasitoids on 27 species of host plants from 10 families; higher number of parasitoids were recorded in samples, which were collected in the open.

Table 1: Check-list of the species, sex ratio and total number of parasitoids recorded in our research.

\begin{tabular}{|c|c|c|c|c|c|c|}
\hline Parasitoid & nr. & ale & nr. & $\%$ & Total & $\begin{array}{l}\% \text { from } \\
\text { the total } \\
\text { number }\end{array}$ \\
\hline Aphidius absinthii Marshall & 2 & 100 & 0 & 0 & 2 & 0.6 \\
\hline Aphidius funebris Mackauer & 3 & 75 & 1 & 25 & 4 & 1.1 \\
\hline $\begin{array}{l}\text { Aphidius matricariae } \\
\text { (Haliday) }\end{array}$ & 76 & 64 & 42 & 36 & 118 & 32.3 \\
\hline Aphidius salicis Haliday & 6 & 54 & 5 & 46 & 11 & 3.0 \\
\hline $\begin{array}{l}\text { Binodoxys acalephae } \\
\text { (Marshall) }\end{array}$ & 16 & 80 & 4 & 20 & 20 & 5.5 \\
\hline $\begin{array}{l}\text { Binodoxys angelicae } \\
\text { (Haliday) }\end{array}$ & 18 & 75 & 6 & 25 & 24 & 6.5 \\
\hline $\begin{array}{l}\text { Binodoxys centaurea } \\
\text { (Haliday) }\end{array}$ & 3 & 50 & 3 & 50 & 6 & 1.6 \\
\hline $\begin{array}{l}\text { Binodoxys heraclei } \\
\text { (Haliday) }\end{array}$ & 2 & 50 & 2 & 50 & 4 & 1.1 \\
\hline $\begin{array}{l}\text { Diaeretiella rapae } \\
\text { (McIntosh) }\end{array}$ & 10 & 42 & 14 & 58 & 24 & 6.5 \\
\hline Ephedrus plagiator (Nees) & 2 & 40 & 3 & 60 & 5 & 1.4 \\
\hline Lipolexis gracilis Förster & 4 & 50 & 4 & 50 & 8 & 2.2 \\
\hline $\begin{array}{l}\text { Lysiphlebus fabarum } \\
\text { (Marshal) }\end{array}$ & 104 & 97 & 3 & 3 & 107 & 29.3 \\
\hline $\begin{array}{l}\text { Monoctonus crepidis } \\
\text { (Haliday) }\end{array}$ & 1 & 100 & 0 & 0 & 1 & 0.3 \\
\hline Praon abjectum (Haliday) & 1 & 100 & 0 & 0 & 1 & 0.3 \\
\hline Praon barbatum Mackauer & 0 & 0 & 1 & 100 & 1 & 0.3 \\
\hline Praon volucre (Haliday) & 6 & 46 & 7 & 54 & 13 & 3.6 \\
\hline Praon yomenae Takada & 6 & 37.5 & 10 & 62.5 & 16 & 4.4 \\
\hline Total & 260 & 71 & 105 & 29 & 365 & 100 \\
\hline
\end{tabular}


We determined the presence of 18 aphid species and 14 of them were parasitised. We identified 365 specimens of parasitoids from 17 species and 8 genera of the family Aphidiidae (Table 1). The most frequent were aphids from the genus Aphis and these were also the most frequently parasitised. From the parasitoids the most frequent were Aphidius matricariae (Haliday) (32.2 \%) and Lysiphlebus fabarum (Marshall) $(29.3 \%)$ (Figure 2). Females were more numerous than males, while from the total number of entraped specimens $71 \%$ were females.

\subsection{Family Fabaceae}

L. fabarum parasitised black bean aphid (Aphis fabae Scopoli), Praon barbatum parasitised pea aphid (Acyrthosiphon pisum [Harris]) and Bionodoxys angelicae parasitised aphid species from genus Aphis.

\subsection{Family Asteraceae}

From the mummies of aphid Uroleucon cichorii (Koch) the parasitoids Aphidius funebris and Praon yomena developed; aphid U. hypochoeridis (Fabricius) was parasitised from $P$. yomena and species Macrosiphoniella millefolii (DeGeer) was parasitised from Aphidius absinthii and Binodoxys centaurea. Black bean aphid was parasitised on Asteraceae plants from Lysiphlebus fabarum, and aphid Aphis fabae cirsiiacanthoides Scopoli from B. acalephae, B. angelicae and Lipolexis gracilis. From the mummies of green peach aphid (Myzus persicae [Sulzer]) the parasitoids of A. matricariae developed. From undeterminated representatives of genus Uroleucon specimens of parasitoid $P$. volucre hatched, while from undetermined representatives of genus Aphis parasitoids A. matricariae and L. fabarum hatched.

On the host plants from the family Asteraceae we found the greatest number of aphids, eight, and also the highest number of parasitoids, namely ten.
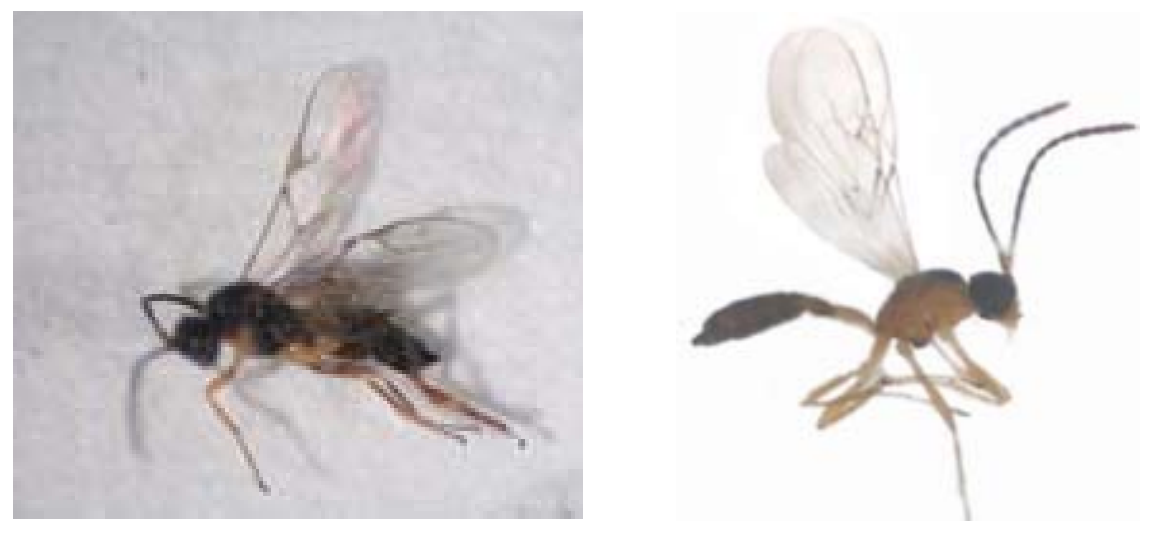

Figure 2: Parasitoids Lysiphlebus fabarum (left, photo: K. Kos) and Aphidius matricariae (right, photo: Ž. Tomanović). 


\subsection{Families Polygonaceae and Chenopodiaceae}

Black bean aphid was parasitised from L. fabarum.

\subsection{Family Apiaceae}

Aphid Cavariella aegopodii (Scopoli) was parasitised from A. salicis and B. heraclei and green peach aphid was parasitised from A. matricariae, Ephedrus plagiator and P. abjectum. From the mummies of aphid Aulacorthum solani (Kaltenbach) parasitoids A. matricariae, E. plagiator and P. abjectum flew out.

\subsection{Family Cucurbitaceae}

Undeterminated specimens from genus Aphis were parasitised from L. fabarum and B. angelicae.

\subsection{Family Solanaceae}

Aphid Aulacorthum solani was parasitised from A. matricariae and from the mummies of unidentified repesentatives of genus Aphis parasitoides L. gracilis, $L$. fabarum, A. matricariae and B. angelicae flew out.

\subsection{Family Boraginaceae}

Aphid Brachycaudus cardui (L.) was parasitised from L. fabarum and B. angelicae.

\subsection{Family Brassicaceae}

D. rapae was determined as parasitoid of aphids $M$. persicae and Brevicoryne brassicae (L.), meanwhile for parasitoids A. matricariae and E. plagiator we found out that they flew out of specimens of green peach aphid.

\subsection{Family Valerianaceae}

Myzus persicae was parasitised from A. matricariae.

Parasitoid Lysiphlebus fabarum parasitised the aphids, which appeared on plant species from seven botanical families: Asteraceae, Fabaceae, Solanaceae, Cucurbitaceae, Polygonaceae, Boraginaceae, and Chenopodiaceae. On the territory of Serbia and Montenegro more than 40 hosts of parasitoid L. fabarum is known and they are found on cultivated and wild-growing plants from eight families (Tomanović, 1998; Tomanović and Brajković, 2001).

Binodoxys angelicae and Aphidius matricariae parasitised aphids from five families of host plants. Parasitoid B. angelicae appeared on the hosts from families Asteraceae, Solanaceae, Fabaceae, Cucurbitaceae and Boraginaceae, while A. matriacriae appeared on the plants from the families Asteraceae, Brassicaceae, Solanaceae, Apiaceae and Valerianaceae. 
The research, which results we represent in a present paper, is a continuation and proportion widening of first investigations of parasitoids on aphids in Slovenia. Latter, which were conducted in the nineties of the past century, namely handeled parasitoids Aphidius matricariae and Diaeretiella rapae on the aphid Rhopalosiphum padi (L.) (Milevoj, 1992) and parasitoid Aphelinus asychis (Walker) on green peach aphid (Milevoj, 1996).

Due to desire for intensive incorporation of biological control in plant protection into the systems of food and ornamental plants production in Slovenia, we want to gain as much information about the abundance and economical importance of different groups of natural enemies as we can. In the framework of the present research we confirmed high diversity of aphid parasitoids from order Hymenoptera in four locations. We ascertain that different species of parasitoids attack different species of aphids on different plant hosts. One of the reason for this we attribute to the known fact that many species of parasitoids are not capable to distinguish between volatile substances, which are excreted by attacked or non-attacked plants (Wyckhuys and Heimpel, 2007). On plant diversified crops (intercropping, strip cropping, trap cropping, weeded fields etc.) the diversity and species richness of natural enemies is higher due to the presence of alternative hosts. These hosts represent source of food and place of refuge to the parasitoids (Bianchi et al., 2006).

Results of our research exhibit great species diversity and wide circulation of parasitoids in vegetable ecosystems on selected locations in Slovenia. That is way we must devote them more attention in the future; as in the framework of research work, as in the actual care for their conservation or even for the increase of their abundance in agroecosystems. The last we can achieve with the application of nonsystemic insecticides in controlling aphids or with the implementation of environmentally friendly systems of plant production (Verkerk et al., 1998).

\section{REFERENCES}

Bianchi, F.J.J.A., Booij, C.J.H., Tscharntke, T. (2006): Sustainable pest regulation in agricultural landscapes: a review on landscape composition, biodiversity and natural pest control. Proc. Royal Soc. B. - Biol. Sci. 273: 1715-1727.

Brajković, M., Tomanović, Ž. (2005): Entomološki praktikum. Metode sakupljanja, preparovanja insekata. Beograd, Biološki fakultet, Univerzitet u Beogradu: 106 p.

Du, L., Ge, F., Zhu, S.R., Parajulee, M.N. (2004): Effect of cotton cultivar on development and reproduction of Aphis gossypii (Homoptera : Aphididae) and its predator Propylaea japonica (Coleoptera : Coccinellidae). J. Econ. Entomol. 97: 12781283.

Godfray H.C.J. (1994): Parasitoids: behavioural and evolutionary ecology. Princeton, New Jersey, Princeton University Press: 473 p.

Hoffmann M.P., Frodsham A.C. (1993): Natural enemies of vegetable insect pests. Ithaca, NY, Cooperative Extension, Cornell University: $63 \mathrm{p}$.

Iversen, T., Harding, S. 2007. Life table parameters affecting the population development of the woolly beech aphid, Phyllaphis fagi. Entomol. Exp. Appl., 123: 109-117. 
Kos, K. (2007): Prave listne uši (Aphididae) in njihovi parazitoidi v vrtnarskem ekosistemu. Dipl. naloga, UL, Biotehniška fakulteta, Odd. za agronomijo: 69 p.

Milevoj L. (1992): Parazitoida Aphidius matricariae Hal. in Diaeretiella rapae M'Intosh (Hym., Aphidiidae) na Rhopalosiphum padi L. (Hom., Aphididae) v Sloveniji. Zb. Bioteh. fak. Univ Ljubl., 59: 163-167.

Milevoj, L. (1991): Preučevanje zoofagne hržice Aphidoletes aphidimyza (Rond.) (Diptera, Cecidomyiidae) v Sloveniji. Zb. Bioteh. fak. Univ. Ljubl., Kmet. 57: 163-167

Milevoj, L. (1996): A study on Aphelinus asychis Walk. in Slovenia. Zb. Bioteh. fak. Univ. Ljubl., Kmet. 67: 115-120.

Milevoj, L. (1997): Effects of food on the adult coccinelids Coccinella septempunctata L. Zb. Bioteh. fak. Univ. Ljubl., Kmet. 69: 137-140.

Minks, A.K., Harrewijn P. (1988): Aphids, their biology, natural enemies and control. World Crop Pests 2B. Amsterdam, Elsevier: 364 p.

Parker, W.E., Howard, J.J., Foster, S.P., Denholm, I. (2006): The effect of insecticide application sequences on the control and insecticide resistance status of the peach-potato aphid, Myzus persicae (Hemiptera : Aphididae), on field crops of potato. Pest Manag. Sci. 62: 307-315.

Starý, P. (1970): Biology of aphid parasitoids (Hymenoptera: Aphidiidae) with respect to integrated control. Series Entomologica, 6: 1-643.

Tomanović, Ž. (1998): Faunistic-ecological and taxonomic study of parasitic wasps (Aphidiidae: Hymenoptera) of agroecosystems of the south part of the Pannonian area. Ph. D. Thesis, Faculty of Biology, University of Belgrade: 641 p.

Tomanović, Ž., Brajković, M. (2001): Aphid parasitoids (Hymenoptera: Aphidiidae) of agroecosystems of the south part of the Pannonian area. Arch. Biol. Sci. 53: 5764.

Trdan, S., Vidrih, M., Valič, N. (2006): Activity of four entomopathogenic nematode species against young adults of Sitophilus granarius (Coleoptera: Curculionidae) and Oryzaephilus surinamensis (Coleoptera: Silvanidae) under laboratory conditions. J. Plant Dis. Prot. 113: 168-173.

Verkerk, R.H.J., Leather, S.R., Wright, D.J. (1998): The potential for manipulating crop-pestnatural enemy interactions for improved insect pest management. Bull. Entomol. Res. 88: 493-501.

Wyckhuys, K.A.G., Heimpel, G.E. (2007): Response of the soybean aphid parasitoid Binodoxys communis to olfactory cues from target and non-target host-plant complexes. Entomol. Exp. Appl. 123: 149-158. 